\title{
SOCIOECONOMIC IMPACTS OF PROTECTION STATUS ON RESIDENTS OF NATIONAL PARKS
}

\author{
Henri Järv ${ }^{1}$ Jaak Kliimask², Raymond Ward ${ }^{3}$, Kalev Sepp ${ }^{4}$
}

Received 18 February 2016; Accepted 3 June 2016

\begin{abstract}
Rural population ageing and decline is a serious problem throughout Europe resulting in a deterioration of the socioeconomic situation in rural areas. This leads to land abandonment, and consequently the loss of valuable cultural landscapes. Protected areas are no exception and inhabitants also face restrictions arising from the protection status. The aim of this study is to identify the existence, extent and nature of the socioeconomic impacts derived from the protection status on the local population. Population and socioeconomic indicators were compared with the results of in-depth interviews with local stakeholders within 2 Estonian national parks and contextualised with recent social change. It was concluded that protected areas have a considerable socioeconomic impact and in order to preserve cultural landscapes, achieve conservation objectives and contribute to balanced regional development, measures must be taken.
\end{abstract}

Keywords: Protected area management, nature conservation, cultural landscapes, natural and cultural heritage, rural development, agricultural land, settlement viability, community development.

Kokkuvõte: Rahvastiku vähenemine ja vananemine on tõsiseks probleemiks terves Euroopas, halvendades sotsiaalmajanduslikku olukorda, eriti maapiirkondades. Muuhulgas kaasneb sellega traditsioonilise maakasutuse hääbumine, ning seeläbi väärtuslike kultuurmaastike hävimine. Kaitsealad asuvad enamasti maapiirkondades ning samalaadsed protsessid on ka neile omased. Lisaks loomulikult moel aset leidvatele muutustele mõjutavad kaitsealade elanikke ka mitmesugused reeglid ja piirangud. Käesoleva uurimuse eesmärgiks oli välja selgitada kaitsestaatusest tuleneva sotsiaalmajandusliku mõju olemasolu, ulatus ja iseloom. Selleks uuriti kahe rahvuspargi, Lahemaa ja Soomaa, rahvastiku- ja sotsiaalmajanduslikke näitajaid ja võrreldi neid väljaspool rahvusparke asuvate külade näitajatega, tehti kohapealseid vaatlusi ning viidi läbi süvaintervjuud huvigruppide esindajatega. Tulemuste analüüsimisel ja tõlgendamisel püüti arvesse võtta uurimisalusel perioodil ühiskonnas toiminud olulisi sündmusi ja muutusi. Uuringu tulemusena leiti, et rahvusparkidel on

\footnotetext{
1 Henri Järv, M.S., Estonian University of Life Sciences, Institute of agricultural and environmental sciences Kreutzwaldi 1, Tartu 51014, Estonia

${ }^{2}$ Ass. Prof. Jaak Kliimask, Estonian University of Life Sciences, Institute of agricultural and environmental sciences Kreutzwaldi 1, Tartu 51014, Estonia

${ }^{3}$ Dr. phil. Raymond Ward, School of Environment and Technology, University of Brighton, Moulsecoomb, Brighton, BN2 4GJ, UK

${ }^{4}$ Prof. Dr. rer. nat. Kalev Sepp, Estonian University of Life Sciences, Institute of agricultural and environmental sciences Kreutzwaldi 1, Tartu 51014, Estonia
} 
oluline sotsiaalmajanduslik mõju ning tasakaalustatud regionaalse arengu tagamiseks, kaitse-eesmärkide saavutamiseks ning väärtuslike kultuurmaastike säilitamiseks on vaja rakendada meetmeid.

\section{Introduction}

Cultural landscapes are formed by long-term co-existence of anthropogenic and natural factors (Vos and Meekes, 1999; Council of Europe, 2000; Antrop, 2006). In Europe, cultural landscapes are considered as part of the common heritage (Council of Europe, 2000; Mitchell and Buggey, 2001; Antrop, 2005). Besides their high ecological value, such landscapes are also considered to be important for the national identity (Antrop, 1997; Millennium ecosystem assessment, 2005; Tengberg et al., 2012). In Estonia, they are highly valued by the public and recognised in national development plans and regulations (Nature Conservation Act, 2004; Arold, 2005; Kaur et al., 2008; Estonian Ministry of the Environment, 2012). Due to social and economic changes, cultural landscapes are threatened and require appropriate protective measures and management (Council of Europe, 2000; Bunce et al., 2001; Green and Vos, 2001; Rescia et al., 2010; Agnoletti, 2014).

Traditional land-use within Europe typically involves utilization of the full scope of available resources (flooded meadows, forests, bogs, agricultural land etc.) (Hurtt et al., 2006) based on the principle of multiple uses (Wilson and Wilson, 1997), whereby resource use is optimised whilst diversifying resource availability, minimizing risk of loss or decreases in the availability of the resources. Within Europe the relative stability and development of these practices has enhanced the structural diversity of vegetation (Joyce and Burnside, 2004; Metsoja et al., 2012; Primdahl et al., 2013; Gerstner et al., 2014). The high nature conservation value of these ecosystems is a by-product of traditional land use (Vos and Meekes, 1999), however, these services together with the land-bound cultural and historical values (Mitchell and Buggey, 2001) are essential components of protected areas (Rescia et al., 2010; Ridding et al., 2015), as are the population required to maintain them (Bridgewater, 2002; Antrop, 2006). The result of decreases or loss of a population to manage resources is a decrease in structural and biodiversity and a decrease in nature value (Stenseke, 2006; Kliimask et al., 2015; Terres et al., 2015).

Previous studies within developing countries including Cameroon, Central African Republic, Equatorial Guinea, Ethiopia, Gabon, Nigeria, Republic of Congo and Madagascar have found that protected areas can have negative impacts on residents including aggravated impoverishment and population loss (Ferraro, 2002; Carnea and Schmidt-Soltau, 2006; Kelboro and Stellmacher, 2015). Conversely, studies from North America and Western Europe report that the establishment of a protected area can positively influence the socioeconomic status of residents in protected areas (Lorah and Southwick, 2003; Bonet-Garcia et al., 2015). Beckmann (2014) poses the question 'does conservation, particularly the establishment of protected natural areas, foster or hinder the economic development of remote rural areas? The studies conducted in subSaharan Africa and North America and Western Europe have sharp contrasts in extremes of poverty and affluence. However, the authors of this study are interested in how protected areas influence the socioeconomic status of residents within an Eastern European context.

The most outstanding cultural landscapes in Estonia are located in the territories of protected areas, especially national parks and landscape reserves (Palang et al., 2011; Estonian Ministry of the Environment, 2012). By the end of 2015, a total of $18.5 \%$ of Estonia's terrestrial area and $28 \%$ of Estonian waters were under protection (approximately $22 \%$ of the country's territory; EELIS, 2016). These figures show that, compared with other countries, Estonia is at the forefront in terms of the area under protection (Juffe-Bignoli et al., 2014) and it can be concluded that cultural landscapes are adequately protected in Estonia. According to recent studies, protection status alone may not be enough to ensure the protection and sustainability of cultural landscapes (WWF, 2004; Mose, 2007; Stoll-Kleemann, 2010; Geldmann et al., 2012; Schmitz et al., 2012; Kliimask et al., 2014; Geldmann et al., 2015). Nature protection policy inspired by ideas of naturalness and wilderness could lead to land abandonment and other negative processes such as shrub encroachment (Fjellstad et al., 2009; Schmitz et al., 2012; Rodríguez-Rodríguez and 
Martínez-Vega, 2013). Human activity and permanent settlement is a precondition for the preservation of cultural landscapes (Höchtl et al., 2005; Fjellstad et al., 2009; Kliimask et al., 2015; Nastran, 2015).

The rural population of Estonia, as in many countries of Europe, is declining and ageing (Sepp, 2011). Employment in the primary sector is decreasing, urbanisation is increasing and as a result the socioeconomic situation in rural areas is deteriorating. The rate of population decline is greater than the national average within protected areas in Estonia. In the last decade, the population of Estonia decreased by an annual average of $0.47 \%$, whilst in protected areas, the population has decreased by $1.2 \%$ over the same period (Kliimask et al., 2014). At the same time other indicators of protected areas are fairly comparable to those of other similar rural areas (Roose et al., 2010; Sepp, 2011; Kliimask et al., 2015).

Managers of protected areas should not be bystanders, solutions must be found to fight these problems. For decision, making it is important to identify the existence, extent and direction of socioeconomic impacts caused by the influence of protection status on the local population, which was the primary aim of this study. For that purpose, a combined method was used including socioeconomic/ demographic data and semi-structured stakeholder interviews.

\section{Overview of governance and management of protected areas in Estonia}

Estonia contains 931 protected areas: 5 national parks, 152 nature reserves, 153 landscape reserves and nature parks, 89 protected areas with unrevised protection rules, and 532 protected parks and stands (EELIS, 2016). The strength and objectives of protection status vary greatly, ranging from limited to strictly protected areas depending on designation. Estonian national parks and nature reserves are divided into one or several strict nature reserves, conservation zones and limited management zones (Kliimask et al., 2014). The current study focuses on limited management zones, where most forestry, agricultural and construction activities occur. $23 \%$ of the protected areas are on private land and it is common that national parks and other protected areas of Estonia have local residents within their boundaries.

The protected areas of Estonia have been governed and managed by the State, and since 2009 the main institution responsible for nature protection is the Environmental Board. The regulation of Environmental Board (2014) states that the organization has six regional branches responsible for the execution of national policies, programs and action plans related to radiation safety, natureand environmental protection and use of natural resources. In last decade the system and institutions of nature conservation have gone through several reforms and became more centralized. Economically it may be cost effective, but it has widened the gap between local inhabitants and nature protection and this can be seen as a negative outcome (BorriniFeyerabend, 2013; Mose, 2007). Prior to 2006, National Parks and some protected areas had their own local administrations, which were located within the territories of protected areas and directly organized conservation management on site. In 2006, the State Nature Conservation Centre (SNCC) was formed and local administrations were closed or turned into visitor centers without any authority. The SNCC and its regional branches coexisted with county environmental services until 2009, when the Environmental Board was formed and replaced both. Considering global trends in governance of protected areas such as shared governance, and the inclusion of communities in decision making processes (Borrini-Feyerabend, 2013), greater centralization and resultant disengagement of populations suggests that in Estonia there is room for improvement.

The Republic of Estonia Nature Conservation Act (adopted in 2004) states that each protected area must have approved protection rules and a conservation management plan, the Environmental Board is responsible for both. The protection rules set the protection regime and these specific for each protected area. Within the legal context, the protection rules provide an additional level of detail to the specifications of the Nature Conservation Act (2004). The conservation management plan sets out a general description of the natural object and its value. The conservation management plan lists the key environmental factors and their impact on the natural object; lists the objectives of protection and their order of priority; provides a detailed work plan for achieving those objectives; provides a timetable and calculates the costs of implementing the objectives. The regulation "preparation and approval of protection management plans and 
determination of approving institution (2009)" the management plan should be drafted for implementation for 3 to ten years dependent on the specific details of the area under protection. There are still a large number of protected areas in Estonia, which do not have valid protection rules and/or conservation management plan resulting in unclear protection regime, objectives, protection zones and management for conservation parties. This creates tensions with stakeholders and makes the achievement of protection objectives difficult.

\section{Material and Methods}

\section{Overview of the study areas}

Lahemaa National Park (LNP) is the oldest and largest national park in Estonia, established in 1971 and located on the north coast (Figure 1), this site was the first national park in the Soviet Union. The total area of the national park is 74784 ha (terrestrial 47910 ha and marine 26874 ha) (Environmental Board, 2016). The majority of the terrestrial area is forested $(73.2 \%)$, with $16 \%$ coverage of open areas and arable land (Figure 2). The protected area is comprised of $\sim 60 \%$ state-owned land and $\sim 40 \%$ private land (Keskkonnaamet, 2016). There are 70 settlements within the national park, with a total of $\sim 3600$ residents according to the population and housing census of 2011 (Statistics Estonia, 2016). The villages are small and several are in danger of becoming abandoned, only a few of them have populations >100 (Kliimask et al., 2014; Kliimask et al., 2015). Based on the management plan currently being formulated, LNP capitalizes on the cooperation between nature, conservation and people - retaining natural and cultural values with the help of its population.

LNP is situated $50 \mathrm{~km}$ from the capital, Tallinn. Good accessibility and a dense road network encourage tourism and commuting - a large proportion of the population work outside the national park. Lahemaa is most popular among single day visitors and compared with Soomaa, Lahemaa provides better and more diverse opportunities for entrepreneurship. The soils of Lahemaa are not very fertile, but forestry and agriculture are widespread (Figure 3 ).

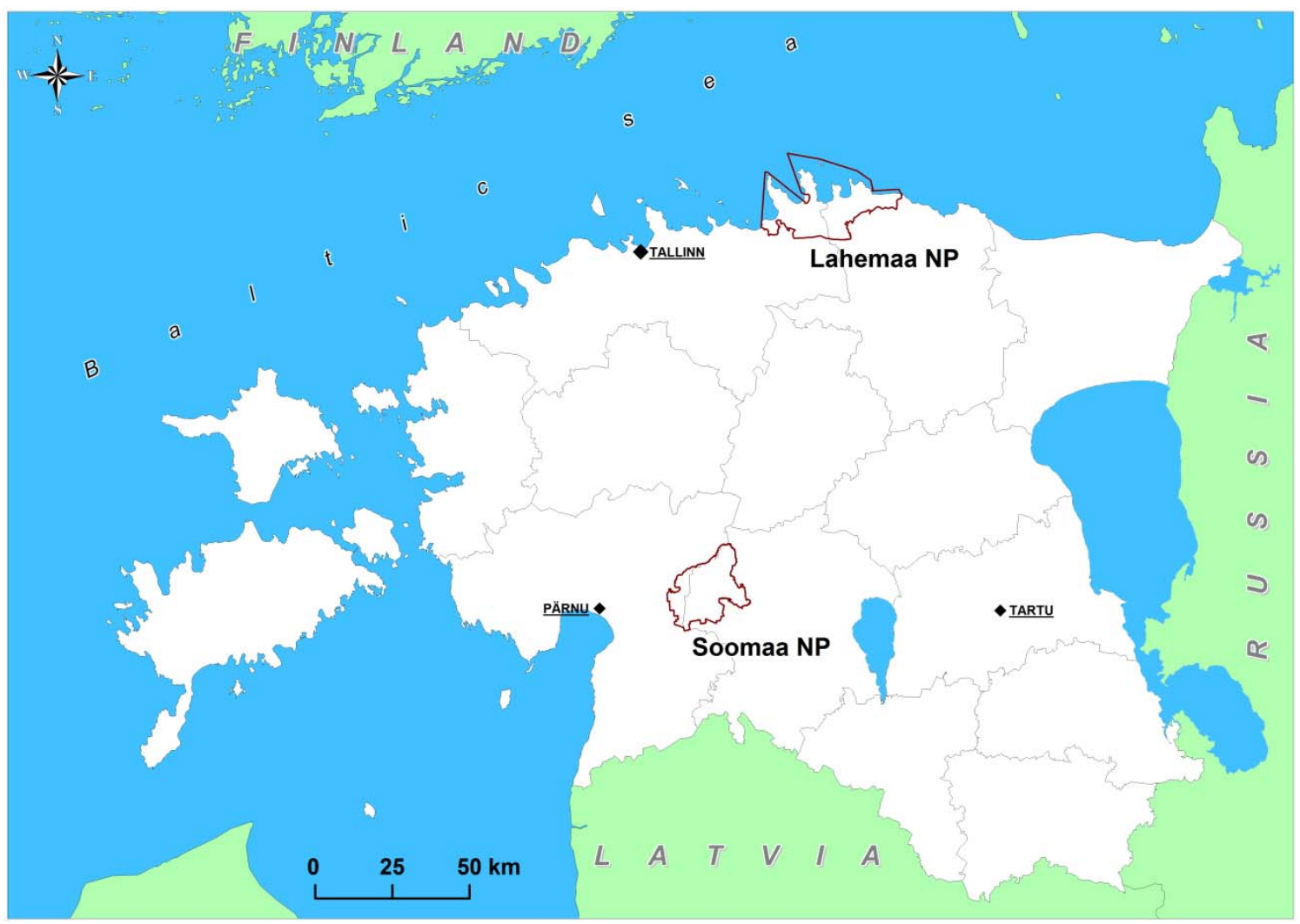

Fig 1. Locations of Soomaa and Lahemaa national parks. 


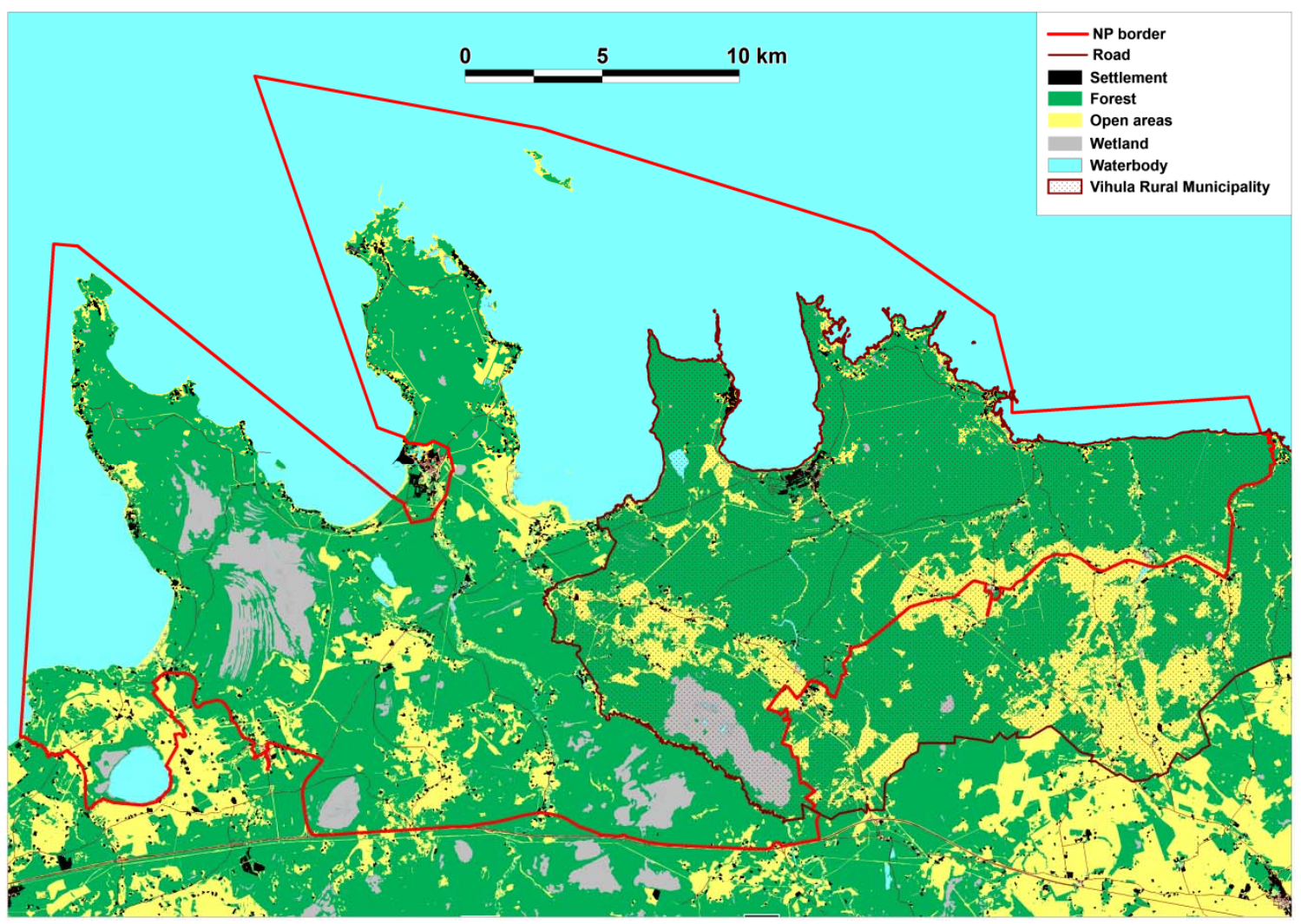

Fig 2. The land cover of Lahemaa National park.

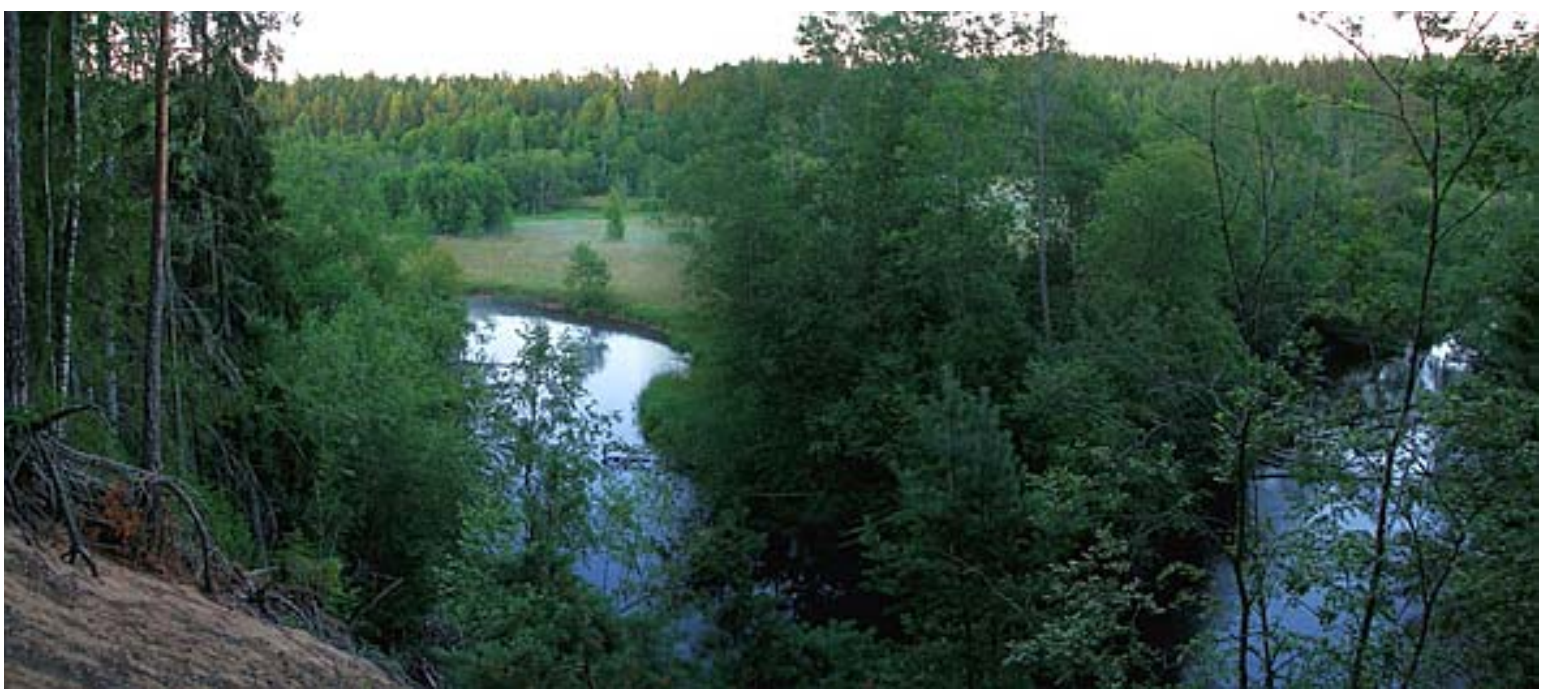

Fig 3. Lahemaa National Park, Valgejõgi. Photo by Hannu, Wikimedia commons.

Soomaa National Park (SNP) was established in 1993 to protect natural and cultural landscapes characteristic of south-western Estonia. The Estonian name Soomaa (Land of Bogs) refers to the fact that bogs with paludified meadows and swamp forests make up 80 per cent of its territory (Figure 4; Environmental Board, 2016). It merged the protected areas: Halliste wooded meadow (protected since 1957) and Valgeraba, Öördi, Kuresoo and Kikerpera bogs (protected since 1981) into a 39000 ha national park. SNP is very sparsely populated $\left(0.14\right.$ inhabitants $\left./ \mathrm{km}^{2}\right)$ with a high nature value. Both the permanent and seasonal population is very low, in 2013 SNP had only 53 permanent inhabitants (Special plan of Soomaa, 2014). The majority of the population are new settlers and vacationers. The road network is sparse with only two main roads traversing the park. Most of the roads are impassable during springtime due to the floods, which decreases accessibility. The primary livelihood in SNP is tourism and landscape management. Agricultural crop production is not possible due to unfavourable environmental conditions (poor soils and 
flooding). Animals are generally kept for landscape management, with animal products such as meat and wool by-products. Management of semi-natural communities is an important source of income for locals. The peculiarity and advantage of Soomaa is that it has a considerably longer tourism period than many protected areas in Estonia, about six months. In spring, visitors come to admire and experience great floods (17500 ha flooded land), the so-called fifth season (Figure $5)$.

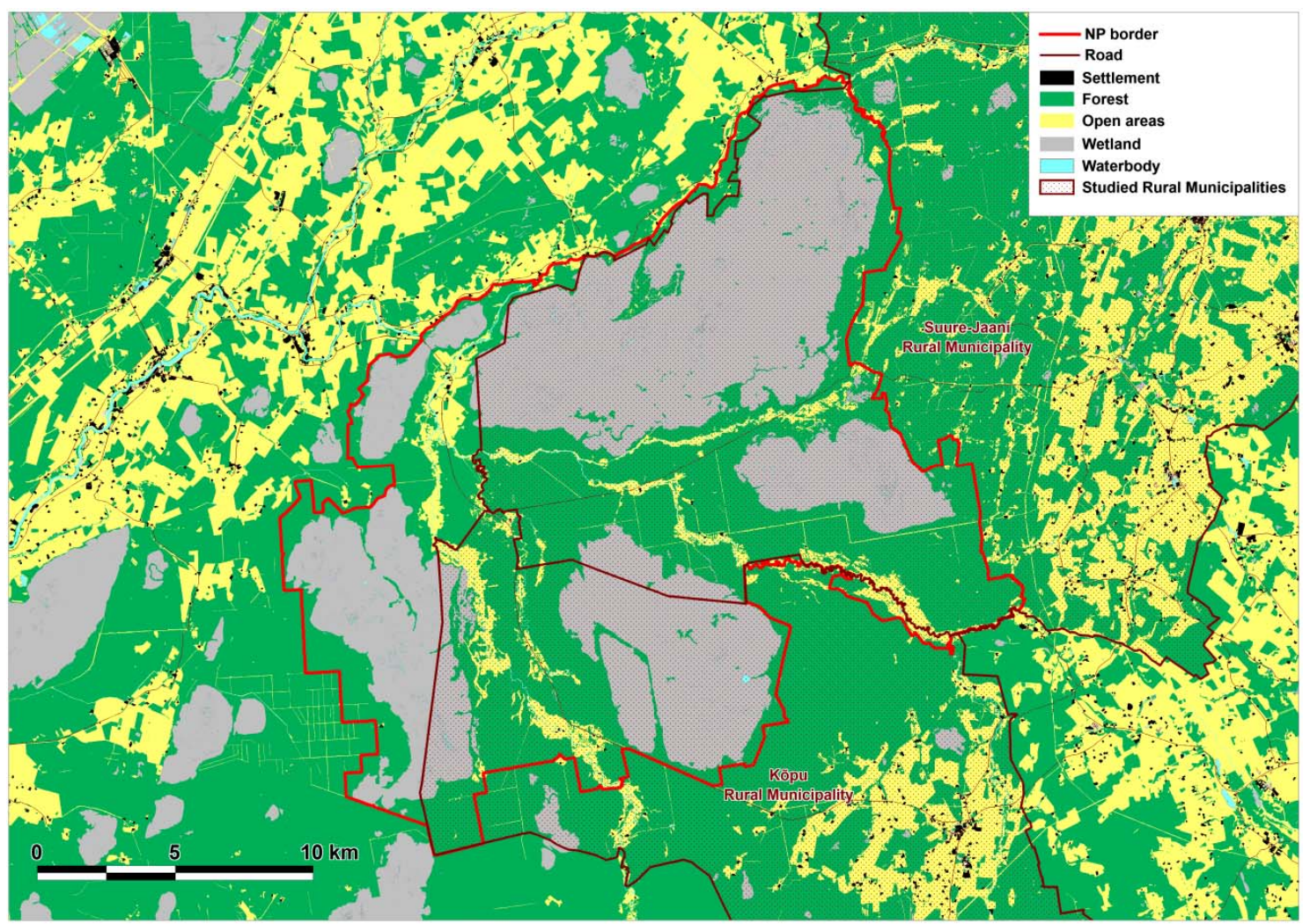

Fig 4. The land cover of Soomaa National Park.

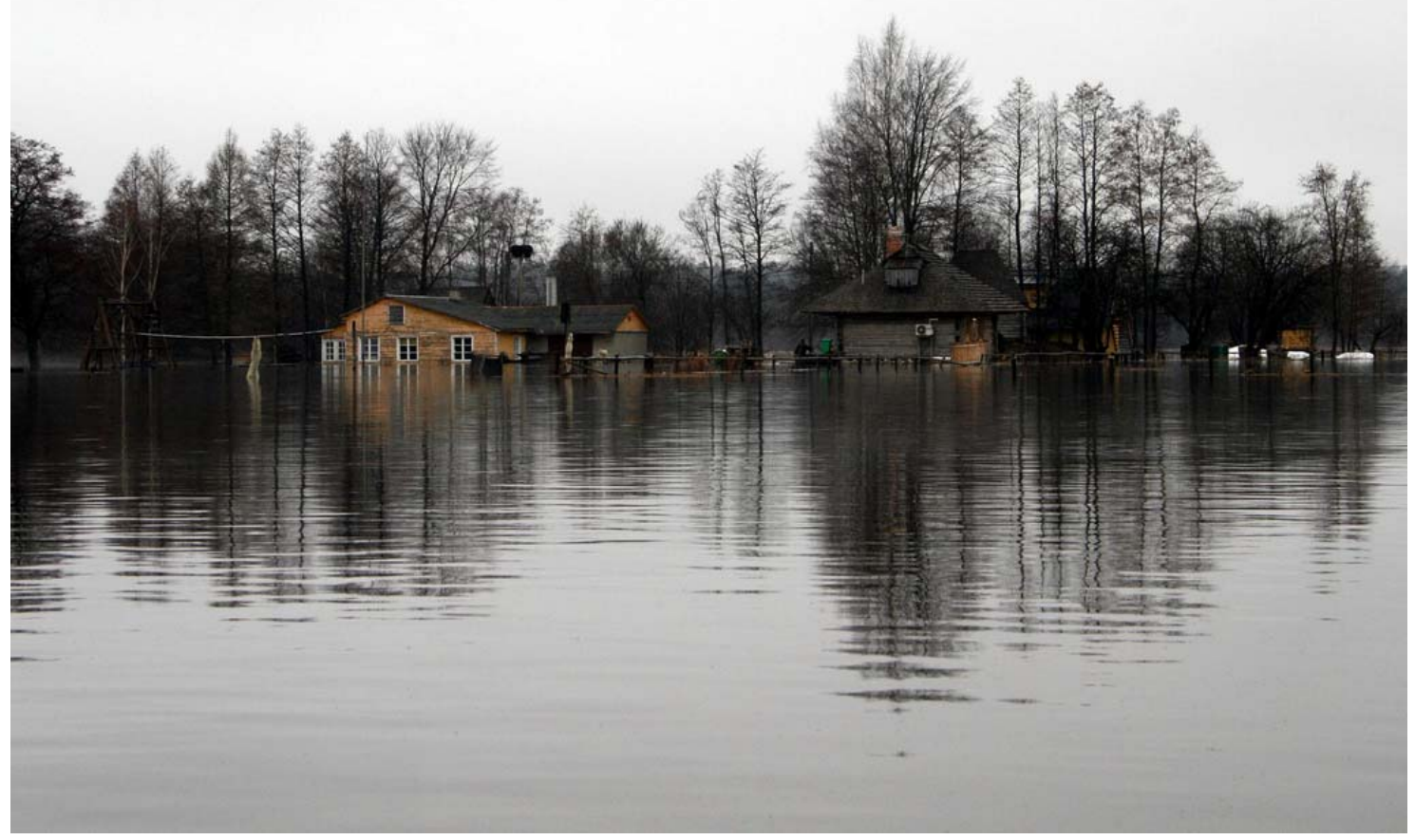

Fig 5. Fifth season in Soomaa provides opportunities for tourism but can also limit other activities (Photo by .waldec shared under licence CC BY 2.0). 


\section{Analysis of socioeconomic parameters}

The areas chosen for the study were Vihula municipality in Lahemaa, and Vastemõisa (now part of Suure-Jaani municipality) and Kõpu municipalities in Soomaa. These two national parks contain some of the most important cultural landscapes in Estonia (Palang et al., 2011) and longterm background data are available for both of these areas and surrounding control villages. Both of these national parks also represent quite distinct natural and cultural landscapes, which enables trend identification to be established, irrespective of their differences and likely driven by their protected status. The study sites include locations both within protected areas and outside of it for comparison. Similar sized villages fully located within the National Parks were used, analysis excluded urban settlements (Võsu, Kõpu, Vastsemõisa) and sites considered to be under the sphere of influence of larger centres, which in this study only included Kuusalu municipality, within LNP. At the village level, the following parameters were investigated: population dynamics; average village size (number of residents); proportion of elderly people (over the age of 65); construction activity (derived from the age of dwellings), and number of empty dwellings (Van Eetvelde and Antrop, 2004; Kliimask et al., 2014; Bonet-García et al., 2015; Terres et al., 2015). The selected socioeconomic parameters were derived from data obtained through the government census surveys, the last of which was carried in 2011 (Statistics Estonia, 2016).

\section{Structured in-depth interviews}

The questionnaire for the semi-structured interviews was compiled with the aim of obtaining qualitative data of residents' perceptions of nature protection legislation. For comparison purposes, the topics of earlier similar studies were taken into consideration when compiling the questionnaire (Kartau, 1998; Niidumaa, 2009). Interviews were conducted during the low tourist and agricultural season in April 2014 and August 2015. In all areas under investigation, interviews were conducted over a one week period, the interview duration varied between 90 minutes and two hours. Snowball sampling was utilised (Yliskylä-Peuralahti, 2003; Palang et al., 2011; Reimann et al., 2011; Nastran, 2015; Steinhäusser et al., 2015) and interviewees and interest groups were selected on the basis of participation in the compilation of the national park's conservation management plans (Keskonnaamet, 2011; Keskkonnaamet, 2016). These included permanent and temporary local residents, either workers or entrepreneurs, from different sectors (forestry, tourism, agriculture, fishing, hunting etc.); officials from the Environmental Board and local municipalities; specialists from the State Forest Management Centre; and land owners. To limit the domination of certain interest groups, preliminary information on potential respondents was collected to include as many interest groups as possible using local networks and initiatives, contacts of acquaintances and organisations engaged in these regions, and simple internet searches (Yliskylä-Peuralahti, 2003; Steinhäusser et al., 2015). On-site, interviewees were asked to recommend further contacts, especially from those interest groups that were not incorporated into the initial sampling (Steinhäusser et al., 2015). All interviews were carried out on-site by direct communication in order to obtain as much relevant information as possible from residents and stakeholders. Interviews were carried out by the same persons in both areas to avoid gathering and processing bias. Altogether 58 interviews were conducted, 32 in LNP, and 26 in SNP.

The questionnaire included twenty seven questions these focused on aspects such as relations between the current regulations of the two national parks and administrative practices, the effects on economic activities and everyday life, forestry and agriculture, building restrictions and real estate development, business and migration.

\section{Results and discussion}

\section{Results of analyses of demographic and socioeconomic indicators}

Population decline and ageing have long been taking place in Estonia, and more intensively in rural areas than urban. In the 60 s, cities developed rapidly, causing the rural youth to migrate to urban areas following the lifting of government restrictions to movement (Paavle, 2011). The population of the capital, increased by 66\% between 1959 and 1989 (Statistics Estonia, 2016). 
In the study areas, population decrease was especially rapid in SNP, with changes considerably greater within the protected area than surrounding areas (Figure 6). Even though the existing protected areas in Soomaa were amalgamated into a national park after 1993, the causes for population decrease during earlier periods were most likely due to unfavourable environmental conditions for agriculture, forestry as well as everyday life. SNP did not follow the national trend during the 1990s, where a deceleration in population decrease or even a slight rise in population occurred. It can be assumed that the foundation of a national park had a negative influence on people living in disadvantageous conditions, which is why the decrease in population was more rapid than in other areas during this period. In recent decades, Soomaa's population decrease has slowed down, those who wished to leave have left, and those that stayed became attached. Interestingly, the population trends are similar both outside the SNP and LNP.

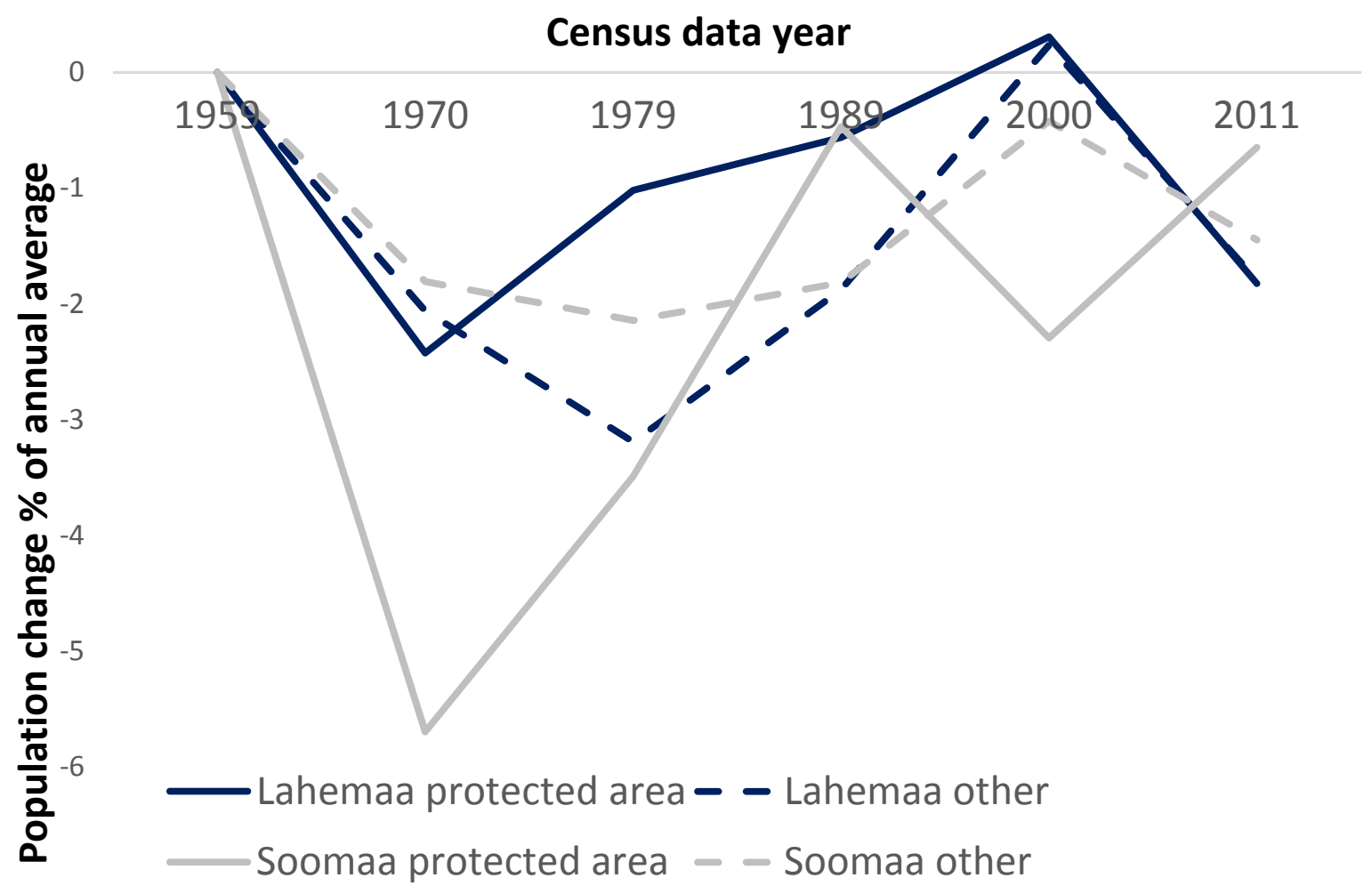

Fig 6. Population change of study areas (based on 1959 baseline) in Soomaa and Lahemaa national parks compared to similar proximal non-protected areas derived from Estonian national census.

Population change has been less variable in LNP than in the surroundings of the LNP as well as within the SNP. The foundation of LNP (1971) and its development took place in an era when Russification was gaining momentum and many people returned to their roots (Kõivupuu et al., 2010). Thus, the increase in population following its formation can be explained by locals valuing the national park as a preserver of national identity. Over the last decade, the population in LNP has decreased reflecting a similar trend to those areas outside the protected area. The reasons for this may lie in LNP's value as an esteemed tourism area, $8 \%$ of Lahemaa's flats and $5 \%$ of single-family dwellings are under foreign ownership, have no permanent residents and are most likely utilised as summer houses.

The average permanent population in villages situated within the study areas has rapidly decreased over the last 50 years and following a similar pattern to national population trends (Tammaru, 2003). SNP saw an especially steep decline, with the average number of residents in villages decreasing by more than $60 \%$ in 11 years (1959-1970).

Outside SNP, this decrease was slower, $20 \%$. Changes within LNP and outside it were quite similar over the same time period as well as the last two decades (1989-2011). Notable, however, is the fact that between 1970 and 1989 (Figure 6), the emptying of villages almost stopped, and 
the population decrease outside the protection area was considerably greater, suggesting that the formation of the national park (1971) slowed population decline.

To analyze the proportion of people greater than working age (over 65s) we took the year 1989 as the beginning of the period, because that was the year with the earliest available statistics. In SNP, the proportion of over 65s fell considerably since 1989 (Figure 7), 10\% in twenty years, and is now below the Estonian average, which was 18.2\% in 2013 (Rosenberg, 2015).

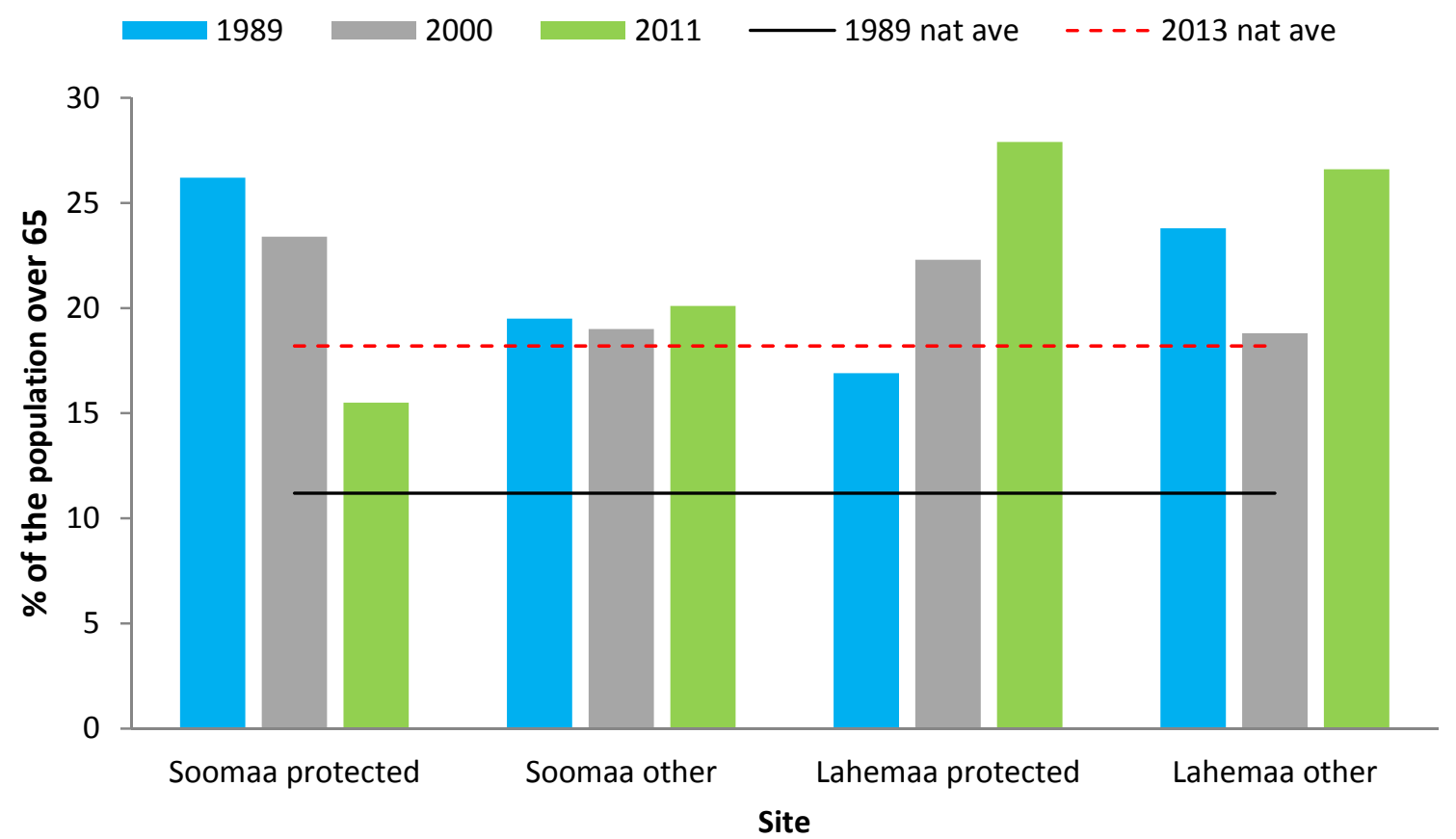

Fig 7. Population greater than working age (over 65) in the Soomaa and Lahemaa national parks and in the surrounding areas between 1989 and 2011 (Statistics Estonia, 2016).

The decreased proportion of over $65 \mathrm{~s}$ is as a result of the migration of younger people away from the area (Nugin, 2015), combined with mortality, leading to a limited replacement of residents over 65 . Areas outside SNP had $\sim 5 \%$ more over 65 s than the protected area, a proportion that remained steady throughout the study period, fluctuating only a percentage point.

The proportion of over $65 \mathrm{~s}$ in LNP rose considerably and rapidly, accounting for $30 \%$ of the population in 2011. This is probably due to a general population ageing (Rosenberg, 2015) as well as the profile of migrants to the area, mainly middle-aged middle-class in part due to its good transport links and dense road network (Kliimask et al., 2015).

The general housing profile in Soomaa and Lahemaa are similar - buildings dating back from before World War II are proportionally fewer in the protected area than outside of them (Figure 8); building activity was greater in the protected areas during the Soviet period, and after regaining independence (1991) greater outside the protected areas. Soomaa has had very few new builds after regaining independence, $<5 \%$ of its total housing (Figure 8 ). This can be explained by the small population and the limits, in practice, to building only on existing plots (Special plan of Soomaa, 2014). The results of the questionnaires showed that people in the area rarely build themselves nor do they sell their plots or property. This results in increased difficulties for those who wish to move into Soomaa. 


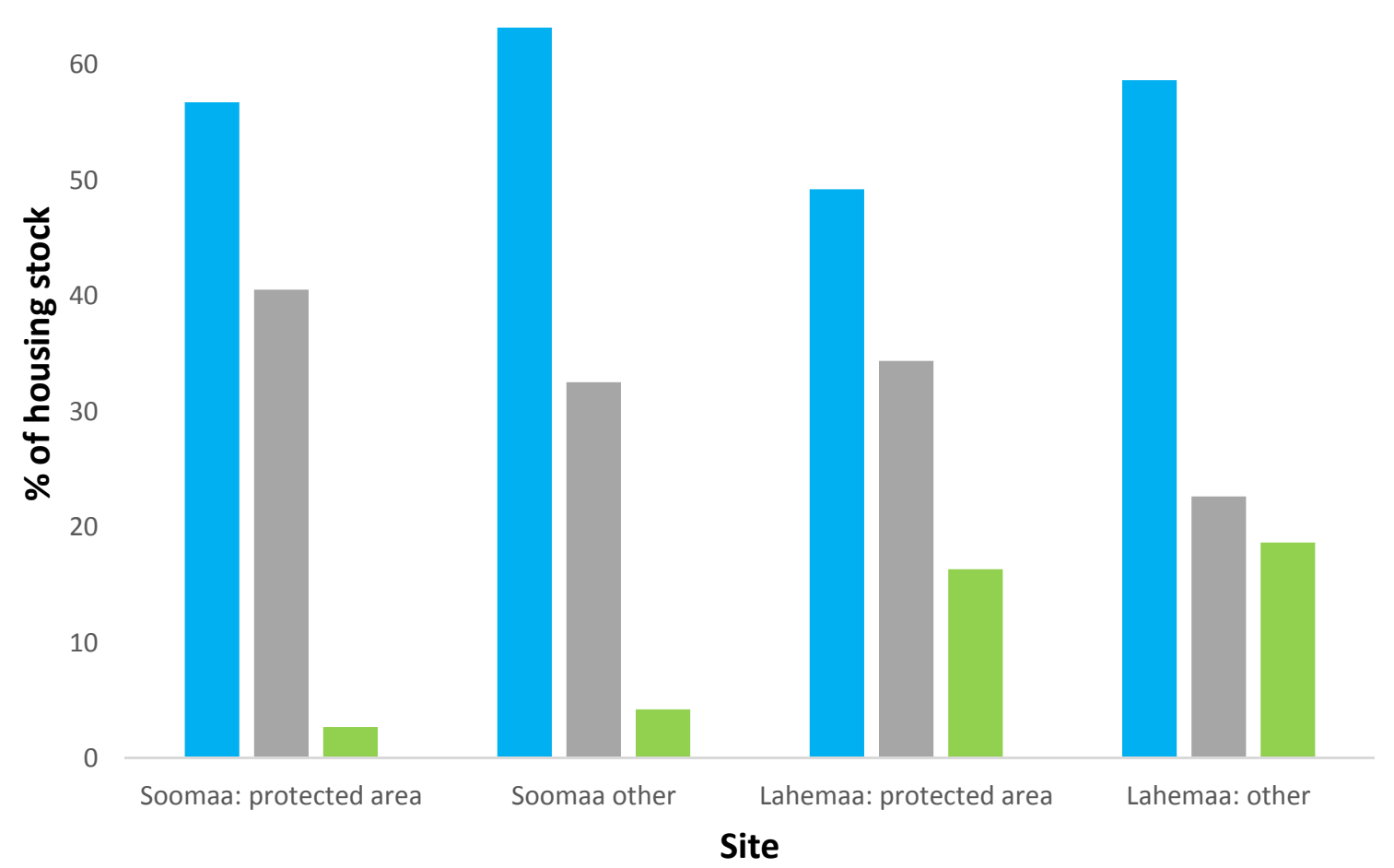

Fig 8. Percentage of housing stock by age of housing (Statistics Estonia, 2016).

However, housing built in LNP after 1991 comprises a fifth of the stock, otherwise there are no relevant differences between villages inside and outside the protected area (Figure 8). Due to good accessibility and the proximity of the capital, the pressure of building is considerably greater than in Soomaa. The housing stock built during the Soviet period is greater within LNP (34\%) than in the surrounding areas (23\%) suggesting that the pressure to build housing within LNP was high, from which it can be concluded that the national park raised the value of the area. The results of the questionnaire suggest that many migrants to the area do not become permanent residents who would contribute to the traditional land use and its living cultural heritage. In addition, there is a perception from residents that this poses other problems the seasonality of services; discordance with the protected area authorities due to the construction pressure; waste management (Farstad and Rye, 2013).

Empty living spaces are more common in the protected areas than outside in both national parks (Figure 9). Thirty percent of the housing stock is empty in SNP, outside of the national park only fifteen percent (Figure 9). LNP has greater than half of the houses empty, with forty percent outside (Figure 9). Permanent residents make up a greater proportion of the population in SNP than in LNP (Figure 9). This is most likely due to the proximity of LNP to the capital, Tallinn, as well as other urban conurbations, which promotes the purchase of dwellings by non-residents for use as second houses. 


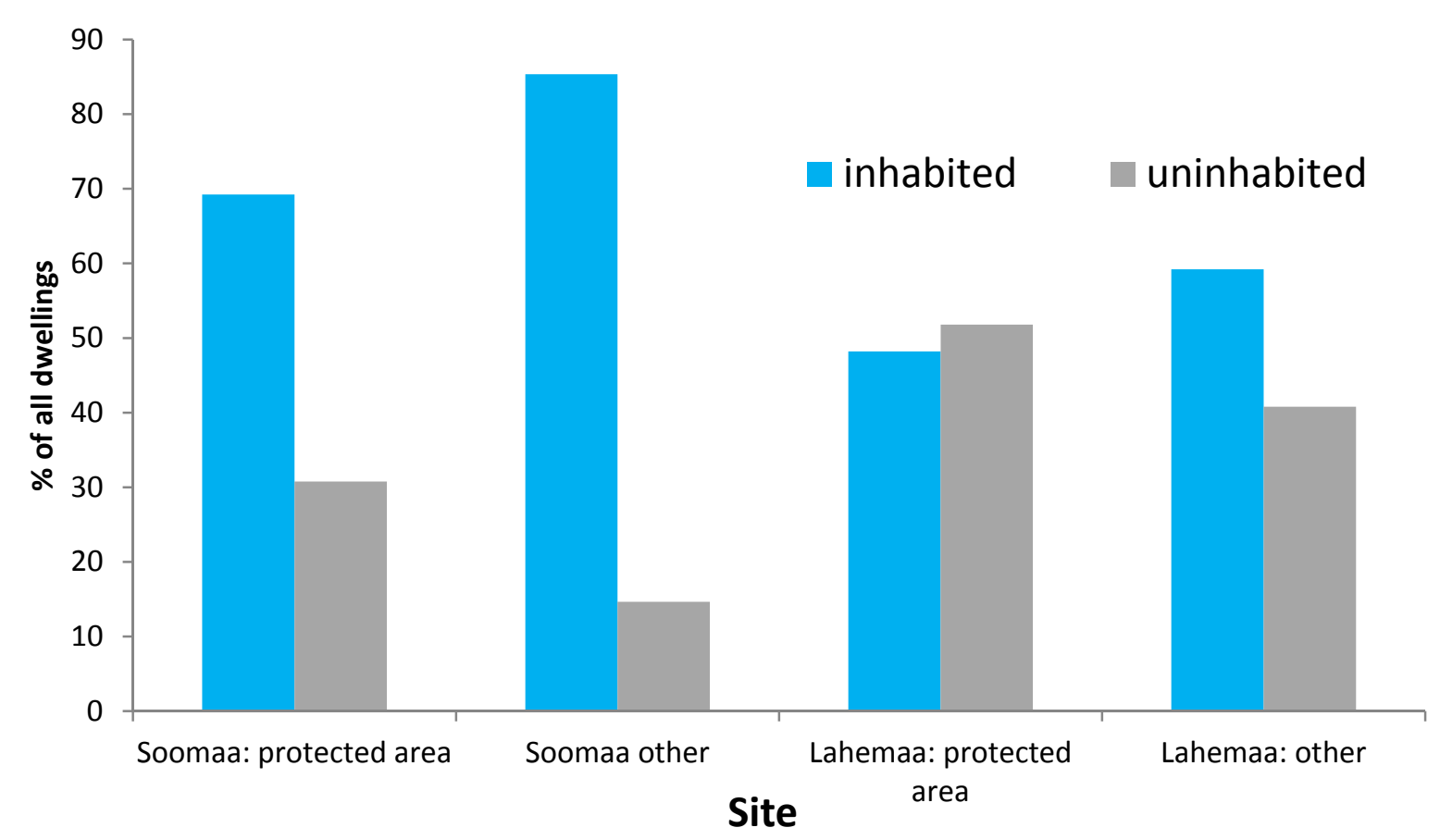

Fig 9. Percentage of dwellings that are inhabited/ uninhabited by permanent residents within the study areas.

\section{Results of in-depth interviews}

The aim of the interviews was to discover how people in the study areas actually lived, identify their attitudes and opinions towards protected areas and nature conservation management practices, and the social and economic impacts resulting from protection status. There were a total of 58 respondents, of which 26 were in Soomaa National Park and 32 in Lahemaa National Park. In order to explain the attitude towards a protected area in general, interviewees were asked to evaluate how living in a protected area affected their freedom of activity and opportunities. As an average, for both of the national parks combined, 18 interviewees out of $58(31 \%)$ found that the protection area influenced their freedom of activity and opportunities in a positive way; 14 respondents $(24 \%)$ assessed the effect as negative, and 22 respondents $(38 \%)$ believed the protection status had no effect on their activities. Results between the two national parks varied. In Soomaa, half of interviewees (13) of interviewees found that the protected area influenced their freedom of activity and opportunities in a positive way, but in Lahemaa only 5 respondents out of $32(16 \%)$ deemed the effect of the protected area positive. National parks as an employer and source of income were seen as positive. Conversely, in Lahemaa 12 (37\%), and in Soomaa 2 respondents $(8 \%)$ considered the effect of the protected area to be negative. The main problem areas identified were related to property and land use, time-consuming procedures and disadvantageous conditions for economic activities. Respondents who considered themselves not influenced by living in a protected area were represented more or less equally in both study areas. Compared to a survey carried out in 2003, the attitude in Soomaa has become considerably more positive (31\% in 2003 to $50 \%$ in 2015) and in Lahemaa slightly more negative (22\% in 2003 to $16 \%$ in 2015) (Niidumaa, 2009).

In Soomaa, nature tourism is a source of income for many residents, which elicits a positive outlook on the national park. Many of the interviewees found that the national park ensures the preservation of the natural environment (a primary factor in their activities) and that without the national park they would not have a job or an income. Niidumaa (2009), found positively disposed interviewees accentuated the national park's role in providing additional income opportunities. In Lahemaa, nature tourism does not have such a focal role and a notable proportion of the population work in agriculture, animal husbandry and forestry, which also accounts for the comparatively more negative attitude towards protection areas (Kächele and Dabbert, 2002; Steinhäusser et al., 2015). The limits and rules of the protection area inhibit their 
actions and the use of resources (land, forest), which has a negative impact on the socioeconomic situation (Kelboro and Stellmacher, 2015).

Generally, the results showed that residents appreciated the fact that their dwelling is situated in a protected area. 21 people deemed it positive in Soomaa (81\%), and 18 in Lahemaa (57\%). Above all, people valued the clean, peaceful environment and the silence. Living in a protected area is taken as a guarantee that the familiar landscape, environment and the resident's income dependant on the natural environment will be preserved (Nastran, 2015). These are the main reasons why the interviewees were opposed to rapid and extensive changes (building of summerhouses, mass migration, and establishment of businesses). Respondents were positively inclined towards modestly-paced changes, to alleviate the problems such as unemployment and marginalization. Another positive that was highlighted was the increase in house values over the past 20 years, which was perceived as related to the location within a protected area (table 1). This increase was related to housing, while the value of land parcels was considered to be decreasing.

\begin{tabular}{|l|c|c|c|c|c|c|}
\hline & \multicolumn{3}{|c|}{$\%$ respondents who believe value } & \multicolumn{3}{c|}{$\%$ respondents who believe value } \\
increased & & \multicolumn{3}{c|}{ decreased } \\
\hline year & $\mathbf{1 9 9 7}$ & $\mathbf{2 0 0 3}$ & $\mathbf{2 0 1 5}$ & $\mathbf{1 9 9 7}$ & $\mathbf{2 0 0 3}$ & $\mathbf{2 0 1 5}$ \\
\hline Soomaa & $10 \%$ & $32 \%$ & $43 \%$ & $41 \%$ & $16 \%$ & $16 \%$ \\
\hline Lahemaa & $38 \%$ & $47 \%$ & $53 \%$ & $28 \%$ & $15 \%$ & $25 \%$ \\
\hline
\end{tabular}

$T a b$ 1. Respondent's opinion about the effect of protected area on the value of real estate (based on data of current study and Kartau, 1998; Niidumaa, 2009).

In Lahemaa, a quarter of the interviewees (8 respondents) deemed living in a protected area as 'somewhat negative', whilst none responded as 'negative'. In Soomaa only one respondent considered living in protected area as 'negative', whilst none responded as 'somewhat negative'. This was predominantly linked to a perception that there were unclear conservation objectives, discontent with nature conservation activities and a lack of functioning dialogue with the community from the national park administration. More than half of the interviewees (35 respondents, 60\%) found that the interests of permanent residents have not been emphasised enough and apparent democracy is taking place: meetings are arranged, opinions are gathered, but the suggestions of local residents do not make it into management plans or other regulatory documents. This disempowerment of the populace can lead to conflicts with nature conservation activities (Pavlikakis and Tsihrintzis, 2006; Tomićević et al., 2010). One of the main conservation objectives of a national park is to preserve the traditional landscapes specific to that area. Alas, landscapes are constantly changing and often conservation objectives do not take this into account (Sepp et al., 1999; Antrop, 2005). A separate question is whether these landscapes are specific to the area and acceptable to residents. One example would be the naturally-grown thicket on the former coastal pastures of Lahemaa. The thicket already corresponds to the notional criteria of a forest and is protected as a Natura habitat, which is why the local residents are not allowed to recover these coastal pastures or graze animals. It can be said that thicketed areas are generally considered a negative phenomenon, not part of the traditional cultural landscape and locals do not consider protecting them appropriate. Fallow lands and thickets were considered the most disturbing factors in Lahemaa, in Soomaa it was considered secondmost disturbing factor after logging. In a study carried out in $2003,78 \%$ in Soomaa and 75\% in Lahemaa of interviewees deemed thickets 'negative' (Niidumaa, 2009).

However, locals' willingness to engage in landscape management is high. $44 \%$ of the interviewees (25 respondents) were willing to help manage the landscapes of their home region under any circumstance, $30 \%$ of the interviewees (17 respondents) would do it if costs were covered, and $21 \%$ (12 respondents; $21 \%$ ) would like to earn income for it. Therefore, almost all of interviewees (54 out of 58; 95\%) were, under varying circumstances, willing to manage the landscapes of their home region. This makes locals a highly motivated but under or poorly utilized resource in landscape management. Thinking of locals as key conservation partners and considering their suggestions has a positive effect in achieving protection objectives (BorriniFeyerabend et al., 2013). Locals expect the authorities of the protected area to take on more 
responsibility in directing the development of rural areas and to actively search for solutions to ensure the viability of the communities by closely cooperating with representatives of these local communities (Fjellstad et al., 2009; Niidumaa, 2009; Tomicevic et al., 2010; Nastran, 2015). In this study it became apparent that the more a protected area limits opportunities and freedom of activity, the more negative the disposition of the populace to the protected area. There is a short distance from weak approval to opposition, which is why resident's complacency deserves special attention. If the residents are not being compensated for the damages caused or the income lost due to the limitations, this can have a negative effect on their already complicated socioeconomic situation and makes preserving cultural landscapes more difficult (Amin et al., 2015).

Human activity and, therefore, permanent settlement is a precondition for the preservation of cultural landscapes (Höchtl et al., 2005; Fjellstad et al., 2009; Kliimask et al., 2015; Nastran, 2015). It is possible to maintain the traditional appearance of a landscape and its accompanying cultural heritage alive artificially, without permanent settlement, but in that case it would essentially be a giant (lifeless) open-air museum (Kõivupuu et al., 2010, Palang et al., 2011). A question is also raised - how large are the areas the state is willing to and can afford to maintain in this state? The problem with privately owned lands can also be added. A large proportion of the land in national parks and protected areas is in private ownership. The results of this study found that the willingness to engage in landscape management is very high - people are often willing to manage the landscape without cost or with their costs being covered, even more if income can be earned from it. Fjellstad et al. (2009) found that where landowners are locals or in some other way motivated (i.e. personal contact or memories, maintaining the region of a summerhouse, etc.), they are willing to contribute to landscape management or at least will not inhibit others from doing so. Our study has also revealed that landowners with a lack of motivation, particularly external players such as real estate businesses, intensive agri-business and others uninterested in traditional landscapes, has led to some areas becoming neglected and overgrown. This is once again one of the reasons why permanent residency should be encouraged in national parks.

There have been efforts to involve local residents and land owners in landscape management though various methods, for which there is an agricultural and environmental program at the state level, and various measures at the landscape level (building stone fences, managing and restoring semi-natural communities, Natura forestry subsidies, etc.) (Suškevičs et al., 2013). Locals were asked whether they consider the national environmental subsidy system functional and adequate. There were no notable differences between the results of the two national parks, 35 respondents (59\%) felt that subsidies were financially inadequate and only 6 respondents $(10 \%)$ found subsidies adequate. Free advisory support was greatly missed particularly advice on the rules and limitations that apply for protected areas and how to come to terms with them. Supposedly, the necessity for advisory support lies in the understanding that monetary subsidies are not rising quickly enough and people need to find other ways of maximizing the use of the opportunities available, without going against the rules of the protected area. Residents felt that because of the limitations that national parks have in place and the expectations that have been placed on people living there (state nature conservation policies carried out by local residents and at their expense), life in a national park should be subsidized. Wells and McShane (2004) found similar results and suggest that poverty alleviation through the sharing of social and economic benefits to build support for protected areas.

With regards to nature conservation policies, 47 interviewees $(81 \%)$ responded that nature conservation limitations were sufficient as they were. According to the interviewees, limitations most affecting them were those concerning property, logging and land use - i.e. those directly influencing people's lives, their direct expenses (i.e. firewood) and income. Limitations on the use of mineral fertilizers and pesticides were not considered relevant, and the influence of other limitations were held to be of little importance or region-specific. Similar results were reached during the studies of 1997 and 2003 (Kartau, 1998; Niidumaa, 2009). Thus, it can be said that no major changes have taken place concerning these questions during the last 20 years.

Where respondents were asked to rank methods for compensating for disadvantages resulting from limitations, the highest ranked response from the majority of interviewees was the favouring of relieved limitations for permanent residents. The next highest ranked response by the majority 
of respondents was the creation of additional alternative income opportunities (jobs, promotion of entrepreneurship, tax incentives, etc.), followed by direct financial compensation. There have been steps taken in connection to various compensation methods, for instance residents of protected areas are provided with land tax incentives and some agricultural subsidies are larger than in other places, but relieving limitations would be a new approach and would merit serious consideration (Kliimask et al., 2015).

\section{Conclusions}

It can be concluded from the studied demographic and construction data that the two studied national parks have a significant socioeconomic impact on residents. Following the foundation of Lahemaa National Park, population decrease and emptying of villages slowed considerably, whilst increasing outside the national park. The proportion of over $65 \mathrm{~s}$ within the population of Lahemaa National Park has gradually increased. Conversely, in Soomaa National Park there was a rapid decrease in the population following its formation, and the proportion of elderly (over 65) residents has been decreasing ever since. This suggests that in remote areas national parks can have a negative effect on residents due to the lower access to amenities as result of distance and greater policy controls than in non-protected areas, on day to day life.

Proportionally there is a greater permanent resident population within Soomaa National Park than Lahemaa, most likely due to the proximity of the Lahemaa National Park to population centres including the capital, Tallinn. In both Lahemaa and Soomaa National Parks, the proportion of uninhabited dwellings is greater within the protected area than without, the majority of these dwellings are owned by non-residents and utilised as summer houses.

Residents themselves consider the socioeconomic impact of the protected areas to be strong. They have to take the requirements of a protected area into account in their everyday life, work, and activities. It is not about what they are not allowed to do, rather that they have to use disproportionate amounts of energy, time and money in dealing with national park related bureaucracy. Decision-makers demand various professional appraisals and documents for development activities for which residents have to cover the costs. These factors directly influence people's income, costs and way of life.

The results of this study have shown that the stability (slow pace of change), cleanliness, and access to a peaceful natural environment are one of the strongest positives of living in the protected area. However, disengagement from the national park administration and unclear conservation objectives were suggested as negatives to life within the protected areas. Consideration of national park residents as key conservation partners is likely to increase feelings of inclusiveness as well as provide a motivated resource to help achieve conservation objectives. Where the national park provides a direct income to residents, such as through nature tourism (Soomaa National Park), this elicits a positive perception to the protected area. However, in Lahemaa National Park, where this activity plays a lesser role, the perception of the role of the protected area is less positive.

It can be said that both the Lahemaa and Soomaa National Park have a substantial socioeconomic impact. Whether that impact is positive or negative has changed over time and is dependent on a range of factors (era, policies set by the authorities, region, economic situation, etc.). This is why past and present data must be analysed to allow an evaluation of influencing factors by comparing the results of questionnaires and contextualising with relevant events.

We can conclude that national parks have both positive and negative socioeconomic impacts on their residents. Positives include slow-paced development and resultant stability, attractive surroundings and negatives include restrictions related to real estate and land-use development, complicated and time-consuming regulatory procedures and disenfranchisement from management decisions. We can also conclude that in some cases this disenfranchisement has impacts on conservation activities.

There is little controversy over the necessity of national parks and other protected areas, and in Europe these typically require anthropogenic input in the form of landscape management. 
However, with large scale losses to populations within national parks this decreases an important resource, residents, from conservation activities.

Decreasing population trends need to be reversed, the authors ask who should pay for the conservation benefits of protected areas, local residents or the population as a whole, and if the whole population, how this should be supported and implemented?

\section{References}

[1] Agnoletti, M. (2014). Rural landscape, nature conservation and culture: Some notes on research trends and management approaches from a (southern) European perspective. Landscape and Urban Planning 126, 66-73. DOI: 10.1016/j.landurbplan.2014.02.012.

[2] Amin, A., Zaehringer, J. G., Schwilch, G. \& Koné, I. (2015). People, protected areas and ecosystem services: a qualitative and quantitative analysis of local people's perception and preferences in Côte d'Ivoire. Natural Resources Forum 39 (2), 97-109. DOI: 10.1111/14778947.12069.

[3] Antrop, M. (1997). The concept of traditional landscapes as a base for landscape evaluation and planning. The examples of Flanders Region. Landscape and Urban Planning 38(1-2), 105-117. DOI: 10.1016/S0169-2046(97)00027-3.

[4] Antrop, M. (2005). Why landscapes of the past are important for the future. Landscape and Urban Planning 70(1-2), 21-34. DOI: 10.1016/j.landurbplan.2003.10.002.

[5] Antrop, M. (2006). Sustainable landscapes: contradiction, fiction or utopia? Landscape and Urban Planning 75(3-4), 187-197. DOI: 10.1016/j.landurbplan.2005.02.014.

[6] Arold, I. (2005). Eesti Maastikud. Tartu Ülikooli kirjastus.

[7] Beckmann, V. (2014). Conservation, Protected Areas and Economic Development of Remote Rural Areas (pp. 209-214). In Dünkel, F. \& Herbst, M., eds., Think Rural! Berlin: Springer Verlag.

[8] Bonet-García, F. J., Pérez-Luque, A. J., Moreno-Llorca, R. A., Pérez-Pérez, R., PuertaPiñero, C. \& Zamora, R. (2015). Protected areas as elicitors of human well-being in a developed region: A new synthetic (socioeconomic) approach. Biological Conservation 187, 221-229. DOI: 10.1016/j.biocon.2015.04.027.

[9] Bunce, R. G. H., Pérez-Soba, M., Elbersen, B., Prados, M. J., Andersen, E., Bell, M. \& Smeets, P.J.A.M. (2001). Examples of European Agri-Environment Schemes and Livestock Systems and their Influence on Spanish Cultural Landscapes. Alterra report 309, Green World Research. Wageningen.

[10] Borrini-Feyerabend, G., Dudley, N., Jaeger, T., Lassen, B., Broome, N. P., Phillips, A. \& Sandwith, T. (2013). Governance of Protected Areas: From understanding to action. Best Practice Protected Area Guidelines Series no. 20. Gland: IUCN.

[11] Bridgewater, P. B. (2002). Biosphere reserves: special places for people and nature. Environmental Science and Policy 5(1), 9-12. DOI: 10.1016/S1462-9011(02)00018-7.

[12] Carnea, M. M. \& Schmidt-Soltau, K. (2006). Poverty Risks and National Park: Policy Issues in Conservation and Resettlement. World Development 34(10), 1808-1830. DOI: 10.1016/j.worlddev.2006.02.008.

[13] Council of Europe (2000). The European Landscape Convention, Strasbourg, [online]. Available: http://www.coe.int/t/dg4/cultureheritage/heritage/Landscape/default_en.asp (Accessed 16.05.2016).

[14] EELIS (2016). Estonian Nature Information System, [online]. Available: http://loodus.keskkonnainfo.ee/eelis/default.aspx (Accessed 17.05.2016). 
[15] Environmental Board (2016). Environmental Board website, [online]. Available: www.keskkonnaamet.ee (Accessed 16.05.2016).

[16] Estonian Ministry of the Environment (2012). Looduskaitse arengukava aastani 2020 [Nature Conservation development plan until 2020, online]. Available: http://www.envir.ee/sites/default/files/lak_lop.pdf (Accessed 17.05.2016).

[17] Farstad, M. and Rye, J. F. (2013). Second home owners, locals and their perspectives on rural development. Journal of Rural Studies 30, 41-51. DOI: 10.1016/j.jrurstud.2012.11.007.

[18] Ferraro, P. J. (2002). The local costs of establishing protected areas in low-income nations: Ranomafana National Park, Madagascar. Ecological Economics 43(2-3), 261-275. DOI: 10.1016/S0921-8009(02)00219-7.

[19] Fjellstad, W., Mittenzwei, K., Dramstad, W. \& Øvren, E. (2009). Landscape protection as a tool for managing agricultural landscapes in Norway. Environmental Science and Policy 12(8), 1144-1152. DOI: 10.1016/j.envsci.2009.01.009.

[20] Geldmann, J., Barnes, M., Coad, L., Graigie, I. D., Hockings, M. \& Burgess, N. D. (2012). Effectiveness of terrestrial protected areas in reducing habitat loss and population declines. Biological Conservation 161, 230-238. DOI: 10.1016/j.biocon.2013.02.018.

[21] Geldmann, J., Coad, L., Barnes, M., Graigie, I. D., Hockings, M., Knights, K., Leverington, F., Cuadros, I. C., Zamora, C., Woodley, S. \& Burgess, N. D. (2015). Changes in protected area management effectiveness over time: A global analysis. Biological Conservation 191, 692-699. DOI: 10.1016/j.biocon.2015.08.029.

[22] Gerstner, K., Dormann, C. F., Stein, A., Manceur, A. M. \& Seppelt, R. (2014). Effects of land use on plant diversity - A global meta-analyses. Journal of Applied Ecology 51(6), 16901700. DOI: 10.1111/1365-2664.12329.

[23] Green, B. \& Vos, W. (2001). Threatened Landscapes: Conserving Cultural Environments. London/New York, Spon Press.

[24] Hurtt, G. C., Frolking, S., Fearon, M. G., Moore, B., Shevliakova, E., Malyshev, S., Pacala, S. W. \& Houghton, R. A. (2006). The underpinnings of land-use history: three centuries of global gridded land-use transitions, wood harvest activity, and resulting secondary lands. Global Change Biology 12(7), 1208-1229. DOI: 10.1111/j.1365-2486.2006.01150.x.

[25] Höchtl, F., Lehringer, S. \& Konold, W. (2005). "Wilderness": what it means when it becomes a reality - a case study from the southwestern Alps. Landscape and Urban Planning 70 (12), 85-95. DOI: 10.1016/j.landurbplan.2003.10.006.

[26] Joyce, C. \& Burnside, N. (2004). Baltic coastal wetlands: back from the brink? National Wetlands Newsletter 26, 11-15.

[27] Juffe-Bignoli, D., Burgess, N. D., Bingham, H., Belle, E. M. S., de Lima, M. G., Deguignet, M., Bertzky, B., Milam, A. N., Martinez-Lopez, J., Lewis, E., Eassom, A., Wicander, S., Geldmann, J., van Soesbergen, A., Arnell, A. P., O'Connor, B., Park, S., Shi, Y. N., Danks, F. S., MacSharry, B. \& Kingston, N. (2014). Protected Planet Report 2014. Cambridge, UK, UNEP-WCMC.

[28] Kartau, K. (1998). The public opinion poll about environmental issues in Estonia. [Master thesis]. University of Tartu and University of Kalmar.

[29] Kaur, E., Kuusik, M. \& Sepp, K. (2008). Eesti Maastikud. Tallinn, Kirjastus Tänapäev, 392 pp.

[30] Kelboro, G. \& Stellmacher, T. (2015). Protected areas as contested spaces: Nech Sar National Park, Ethiopia, between "local people", the state, and NGO engagement. Environmental Development 16, 63-75. DOI: 10.1016/j.envdev.2015.06.005.

[31] Keskkonnaamet (2011). Soomaa rahvuspargi kaitsekorralduskava 2011-2020 Available: http://www.keskkonnaamet.ee/public/soomaa/Soomaa_RP_kaitsekorralduskava.pdf (Accessed 11.05.2016) 
[32] Keskkonnaamet (2016). Lahemaa rahvuspargi kaitsekorralduskava 2016-2025 Available: http://www.keskkonnaamet.ee/public/Lisa_1_Lahemaa_RP_KKK_2016-2025.pdf (Accessed 11.05.2016).

[33] Kliimask, J., Järv, H., Sepp, K. \& Ward, R. (2014). Nature conservation in remote rural areas: a win-win situation? (pp. 193-208). In Dünkel, F. \& Herbst, M., eds., Think Rural! Berlin: Springer Verlag.

[34] Kliimask, J., Parts, P-K., Järv, H., Sepp, K. \& Ward, R. (2015). Endangered settlements and protected areas in Estonia: the challenge of maintaining cultural landscapes. International Journal of Agricultural Resources, Governance and Ecology 11, 346-368.

[35] Kõivupuu, M., Printsmann, A. \& Palang, H. (2010). From inventory to identity - cultural built heritage management in the Lahemaa National Park, Estonia (pp. 115-131). In Bloemers, J. H. F. et al., eds., The Cultural Landscape Heritage Paradox: Protection and Development of the Dutch Archaeological-Historical Landscape and its European Dimension. Amsterdam: University of Amsterdam Press.

[36] Kächele, H. \& Dabbert, S. (2002). An economic approach for a better understanding of conflicts between farmers and nature conservationists - an application of the decision support system MODAM to the Lower Odra Valley National Park. Agricultural Systems 74(2), 241-255. DOI: 10.1016/S0308-521X(01)00087-7.

[37] Metsoja, J-A., Neuenkamp, L., Pihu, S., Vellak, K., Kalwij, J. M. \& Zobel, M. (2012). Restoration of flooded meadows in Estonia - vegetation changes and management indicators. Applied Vegetation Science 15(2), 231-244. DOI: 10.1111/j.1654109X.2011.01171.X.

[38] Millennium Ecosystem Assessment (2005). Ecosystems and Human Well-being: Synthesis. Washington, DC, Island Press.

[39] Mitchell, N. \& Buggey, S. (2001). Protected landscapes and cultural landscapes: taking advantage of diverse approaches. George Wright Forum 17, 35-46.

[40] Mose, I. (2007). Protected Areas and Regional Development in Europe. Towards a New Model for the $21^{\text {st }}$ Century. Hampshire: Ashgate Publishing.

[41] Nastran, M. (2015). Why does nobody ask us? Impacts on local perception of a protected area in designation, Slovenia. Land Use Policy 46, 38-49. DOI: 10.1016/j.landusepol.2015.02.001.

[42] Nature Conservation Act (2004) [online]. Available: https://www.riigiteataja.ee/en/eli/ee/508112013010/consolide/current $\quad$ (Accessed 16.05.2016).

[43] Niidumaa, M. (2009). Looduskaitseliste küsimuste ja probleemide analüüs kaitsealadel läbi kohalike vaateprisma [Master thesis]. Tartu: University of Life Sciences.

[44] Nugin, R. (2014). "I think that they should go. Let them see something". The context of rural youth's out-migration in post-socialist Estonia. Journal of Rural Studies 34, 51-64. DOI: 10.1016/j.jrurstud.2014.01.003.

[45] Paavle, I. (2011). Ebaühtlane ühtne süsteem. Sovetliku passisüsteemi rakendamine ENSVs [in english available online: http://www.mnemosyne.ee/wordpress/wpcontent/uploads/2011/06/Indrek_Paavle_-_Passport_System_II.pdf]. Tuna 2, 43-67.

[46] Palang, H., Alumäe, H., Printsmann, A., Rehema, M., Sepp, K. \& Sooväli-Sepping, H. (2011). Social landscape: Ten years of planning "valuable landscapes" in Estonia. Land Use Policy 28(1), 19-25. DOI: 10.1016/j.landusepol.2010.04.004.

[47] Pavlikakis, G. E. \& Tsihrintzis, V. A. (2006). Perceptions and preferences of the local population in Eastern Macedonia and Thrace National Park in Greece. Landscape and Urban Planning 77(1), 1-16. DOI: 10.1016/j.landurbplan.2004.12.008. 
[48] Primdahl, J., Kristensen, L. S. \& Busck, A. G. (2013). The Farmer and Landscape Management: Different Roles, Different Policy Approaches. Geography Compass 7(4), 300314. DOI: $10.1111 / \mathrm{gec} 3.12040$.

[49] Regulation of preparation and approval of protection management plans and determination of approving institution, 2009 [Kaitsekorralduskava koostamise ja kinnitamise kord ning kaitsekorralduskava kinnitaja määramine, online]. Available: https://www.riigiteataja.ee/akt/128062013017?leiaKehtiv (Accessed 15.05.2016).

[50] Regulation of Environmental Board (2014). [Keskkonnaameti põhimäärus, online]. Available: https://www.riigiteataja.ee/akt/127052014001 (Accessed 13.05.2016).

[51] Reimann, M., Lamp, M-L. \& Palang, H. (2011). Tourism Impacts and Local Communities in Estonian National Parks. Scandinavian Journal of Hospitality and Tourism 11(Suppl. 1), 8799. DOI: $10.1080 / 15022250.2011 .638206$.

[52] Rescia, A. J., Willaarts, B. A., Schmitz, M. F. \& Aguilera, P. A. (2010). Changes in land uses and management in two Nature Reserves in Spain: Evaluating the social-ecological resilience of cultural landscapes. Landscape and Urban Planning 98(1), 26-35. DOI: 10.1016/j.landurbplan.2010.07.007.

[53] Ridding, L. E., Redhead, J. W. \& Pywell, R. F. (2015). Fate of semi-natural grassland in England between 1960 and 2013: A test of national conservation policy. Global Ecology and Conservation 4, 516-525. DOI: 10.1016/j.gecco.2015.10.004.

[54] Rodríguez-Rodríguez, D. \& Martínez-Vega, J. (2013). Results of the implementation of the System for the Integrated Assessment of Protected Areas (SIAPA) to the protected areas of the Autonomous Region of Madrid (Spain). Ecological Indicators 34, 210-220. DOI: 10.1016/j.ecolind.2013.04.019.

[55] Roose, A., Raagmaa, G. \& Kliimask, J. (2010). Rural development trajectories in the Estonian periphery: impacts of the EU Cohesion Policies. The Regional Studies Association Annual International Conference proceedings. 24 - 26 May 2010. Pecs, Hungary.

[56] Rosenberg, T. (2015). Population trends. Tallinn, Statistics Estonia.

[57] Schmitz, M. F., Matos, D. G. G., De Aranzabal, I., Ruiz-Labourdette, D. \& Pineda F. D. (2012). Effects of a protected area on land-use dynamics and socioeconomic development of local populations. Biological Conservation 149, 122-135. DOI: 10.1016/j.biocon.2012.01.043.

[58] Sepp, E. (2011). Regional development trends in Estonia during the recent years (pp. 2939). In Narusk, E., ed., Regional development in Estonia 2011, Tallinn: Statistics Estonia.

[59] Sepp, K., Palang, H., Mander, Ü. \& Kaasik, A. (1999). Prospects of nature and landscape protection in Estonia. Landscape and Urban Planning 46(1), 161-167. DOI: 10.1016/S01692046(99)00041-9.

[60] Special plan of Soomaa (2014). [Soomaa piirkonna teemaplaneering, online] Available: http://parnu.maavalitsus.ee/documents/181369/5117430/Soomaa+piirkonna+teemaplaneer ingu+esimese+eskiislahenduse+seletuskiri.pdf/90f14d5f-544c-4a51-9569-08972815f778 (Accessed 15.05.2016).

[61] Statistics Estonia (2016). Statistics Estonia website [online] Available: www.stat.ee (Accessed 13.05.2016).

[62] Steinhäußer, R., Siebert, R., Steinführer, A. \& Hellmich, M. (2015). National and regional land-use conflicts in Germany from the perspective of stakeholders. Land Use Policy 49, 183-194. DOI: 10.1016/j.landusepol.2015.08.009.

[63] Stenseke, M. (2006). Biodiversity and the local context: Linking semi-natural grassland and their use to social aspects. Environmental Science and Policy 9(4), 350-359. DOI: 10.1016/j.envsci.2006.01.007. 
[64] Stoll-Kleemann, S. (2010). Evaluation of management effectiveness in protected areas: Methodologies and results. Basic and Applied Ecology 11(5), 377-382. DOI: 10.1016/j.baae.2010.06.004.

[65] Suškevičs, M., Tillemann, K. \& Külvik, M. (2013). Assessing the relevance of stakeholder analysis for national ecological network governance: The case of the Green Network in Estonia. Journal of Nature Conservation 21(4), 206-213. DOI: 10.1016/j.jnc.2012.12.007.

[66] Tammaru, T. (2003). Urban and rural population change in Estonia: patterns of differentiated and undifferentiated urbanisation. Tijdschrift voor economische en sociale geografie 94(1), 112-123. DOI: 10.1111/1467-9663.00241.

[67] Tengberg, A., Fredholm, S., Eliasson, I., Knez, I., Saltzman, K. \& Wetterberg, O. (2012). Cultural ecosystem services provided by landscapes: Assessment of heritage values and identity. Ecosystem Services 2, 14-26. DOI: 10.1016/j.ecoser.2012.07.006.

[68] Terres, J. T., Scacchiafichi, L. N., Wania, A., Ambar, M., Anguiano, E., Buckwell, A., Coppola, A., Gocht, A., Nordström Källström, H., Pointereau, P., Strijker, D., Visek, L., Vranken, L. \& Zobena, A. (2015). Farmland abandonment in Europe: Identification of drivers and indicators, and development of a composite indicator of risk. Land Use Policy 49, 20-34. DOI: 10.1016/j.landusepol.2015.06.009.

[69] Tomicevic, J., Shannon, M. A. \& Milovanovic, M. (2010). Socio-economic impacts on the attitudes towards conservation of natural resources: Case study from Serbia. Forest Policy and Economics 12(3), 157-162. DOI: 10.1016/j.forpol.2009.09.006.

[70] Van Eetvelde, V. \& Antrop, M. (2004). Analyzing structural and functional changes of traditional landscapes - two examples from Southern France. Landscape and Urban Planning 67(1-4), 79-95. DOI: 10.1016/S0169-2046(03)00030-6.

[71] Vos, W. \& Meekes, H. (1999). Trends in European cultural landscape development: perspectives for a sustainable future. Landscape and Urban Planning 46(1-3), 3-14. DOI: 10.1016/S0169-2046(99)00043-2.

[72] Wells, M. P \& McShane, T. O. (2004). Integrating Protected Area Management with Local Needs and Aspirations. Ambio 33, 513-519.

[73] Wilson, O. J. \& Wilson, G. A. (1997). Common cause or common concern? The role of common lands in the post-productivist countryside. Area 29(1), 45-58. DOI: 10.1111/j.14754762.1997.tb00006.x.

[74] WWF (2004). Are protected areas working? An analysis of forest protected areas by WWF. Gland, WWF International.

[75] Yliskylä-Peuralahti, J. (2003). Biodiversity - a new spatial challenge for Finnish agrienvironmental policies? Journal of Rural Studies 19(2), 215-231. DOI: 10.1016/S07430167(02)00070-0. 